\title{
ANALISIS DAMPAK EKONOMI PEDAGANG KAKI LIMA DI KOTA BOGOR DENGAN PENDEKATAN INPUT OUTPUT ANALYSIS
}

\author{
Economic Impact Analysis of cadger Traders in Bogor City Using an Output Analysis \\ Approach
}

\author{
Syarief Gerald Prasetya ${ }^{1}$, Yustiana Wardhani ${ }^{2}$
}

\author{
${ }^{1}$ Staf Pengajar Program Studi Akuntansi. STIE Binaniaga. Email: er7et70@gmail.com \\ ${ }^{2}$ Staf Pengajar Program Studi Manajemen. STIE Binaniaga. Email: yustiana.wardhani@yahoo.com
}

\begin{abstract}
A very high jobless people in the city has created an informal sector. This informal sector has become an alternative way for them to find a job. It has happened since it is very relatively easy joining or leaving this informal sector as there is not any particular regulation required. This research aims to study the contribution of street stalls upon the multiplier output, revenue, employment and forward-backward linkage over the economy. Method of analysis has been using input-output analysis and the research location has taken place in Bogor. The result of the research has indicated that the availability of the street stalls in the city cannot be considered as a marginal sector as they have been contributing positively the city economy either in the multiplier analysis or forward-backward linkage. Organizing and registering the street stalls in Bogor should have to be executed properly and periodically in order to find out their economical potential, making sure that they will not jeopardize the landscape of public facility. However, a particular association should have to be established in order to ease the supervision of the street stalls and to improve their quality accordingly.
\end{abstract}

Keyword: Street stalls, informal sector, output, revenue, manpower

\begin{abstract}
ABSTRAK
Tingginya tingkat pengangguran perkotaan menumbuhkan sektor informal. Pedagang kaki lima merupakan salah satu sektor informal menjadi alternatif bagi mereka yang tidak mendapatkan pekerjaan disebabkan mudahnya untuk masuk dan keluar di sektor informal relatif mudah karena tidak ada aturan secara khusus yang mensyaratkan. Penelitian ini bertujuan untuk mengetahui kontribusi pedagang kaki lima terhadap multiplier output, pendapatan, penyerapan tenaga kerja dan forward-backward linkage terhadap perekonomian. Metode analisis yang digunakan adalah analisis input-output dan lokasi penelitian di Kota Bogor. Hasil penelitian menunjukan keberadaan pedagang kaki lima perkotaan tidak dapat dipandang sebagai sektor yang marginal, pedagang kaki lima memberikan kontribusi positif terhadap perekonomian perkotaan baik dalam analisis multiplier dan analisis forward-backward linkage. Penataan dan pendataan pedagang kaki lima di Kota Bogor perlu dilakukan secara periodik agar dapat diketahui potensi ekonomi, tidak mengganggu landscap dan peruntukan fasilitas umum kota. Perlunya pembentukan assosiasi agar dapat lebih mudah dalam pengawasan dan upaya peningkatan kualitas pedagang kaki lima.
\end{abstract}

Kata Kunci : Pedagang Kaki Lima, Sektor Informal, Output, Pendapatan, Tenaga Kerja

\section{PENDAHULUAN}

Problematika perkotaan saat ini semakin tumbuh dan berkembang menyebabkan semakin sulitnya

100 pemerintah, khususnya pemerintah daerah mencari solusi mengatasi masalah tersebut. Di satu sisi permasalahan yang timbul di daerah perkotaan semakin kompleks dan rumit, namun di sisi lain kemampuan dan sumber daya yang dimiliki pemerintah masih terbatas. Hal ini juga dirasakan oleh Pemerintahan Kota Bogor yang kepadatan penduduknya cenderung semakin meningkat setiap tahunnya. Kurangnya 
kemampuan wilayah perkotaan dalam menampung penduduk tersebut menyebabkan timbulnya permasalahanpermasalahan seperti tingkat pengangguran kota yang semakin tinggi, tingkat kriminalitas yang semakin berkembang dan diperparah lagi dengan kurang memadainya sarana pelayanan publik di bidang kesehatan, pendidikan, transportasi. Kondisi seperti ini dirasakan oleh seluruh wilayah perkotaan yang ada di Indonesia, sehingga permasalahan perkotaan menjadi prioritas penting dalam upaya membanguan kehidupan bangsa.

Kota menjadi magnet penduduk desa untuk memenuhi kebutuhan. Meskipun di perkotaan peluang usaha tersedia lebih besar, namun karena bekal keahlian dan keterampilan yang terbatas, maka tidak mudah bagi pencari kerja untuk mamasuki sektor formal yang hampir selalu diperlukan syarat formal seperti ijazah suatu pendidikan tertentu. Kondisi ini menyebabkan tingkat pengangguran wilayah perkotaan semakin tinggi. Tingginya tingkat pengangguran ini menumbuhkan sektor informal di wilayah perkotaan. Sektor informal menjadi salah satu alternatif bagi mereka yang tidak mendapatkan pekerrjaan disebabkan untuk masuk dan keluar di sektor relatif mudah karena tidak ada aturan secara khusus yang mensyaratkan. Kemudian untuk kepemilikan dan pengelolaan umumnya bersifat kekeluargaan sehingga dapat memanfaatkan keluarga sendiri atau teman-teman yang ada. Selain itu usaha yang dijalankan relatif berskala kecil sehingga lebih pada karya dengan teknologi yang masih tradisional dan begitu membutuhkan modal besar serta sektor ini tidak membutuhkan keahlian khusus, dan pasar bersifat kompetitif tetapi tidak disertai regulasi yang jelas.

Semakin beragamnya sektor informal menyebabkan sulit membedakan dengan sektor formal. Hal ini dikarenakan dalam sektor informal terdapat kesatuan rangkaian antara usaha berskala kecil dengan yang berskala besar, illegal dan legal serta yang produktif dengan yang kurang produktif. Aktivitas yang mereka jalankan sangat beragam, mulai dari penjaja makanan, jasa ojek, sampai pada para penjual barang-barang elektronik bajakan dan lain sebagainya. Mereka tidak memiliki cukup modal untuk meningkatkan skala usahanya sehingga tidak cukup untuk menghidupi keluarganya. Kondisi menyebabkan orientasi sektor informal bukan pada pemupukan modal, tetapi lebih pada upaya memperoleh pendapatan cash yang langsung dapat dibelanjakan untuk memenuhi kebutuhan rumah tangga.

Pedagang kaki lima merupakan salah satu kegiatan sektor informal yang paling banyak digeluti dan memiliki keragaman yang tinggi. Usaha ini memiliki kecenderungan yang semakin berkembang setiap waktunya. Kegiatan perdagangan yang dijalankan oleh aktivitas ini sangat beragam seperti menjual makanan, pakaian, rokok dan barang-barang kebutuhan lain yang memiliki harga relatif murah. Kemunculan pedagang kaki lima berdampak semakin meningkatnya ketersediaan jumlah barang dan jasa yang dibutuhkan masyarakat. Hal ini dapat dirasakan oleh seluruh golongan ekonomi karena harga produk ataupun jasa yang ditawarkan oleh pedagang kaki lima cukup terjangkau untuk golongan bawah sampai dengan atas.

Selain itu pedagang kaki lima merupakan salah satu solusi alternatif dalam menurunkan tingkat pengangguran di wilayah perkotaan. Peran penting pedagang kaki lima di perkotaan adalah sebagai katup pengaman penyedia lapangan pekerjaan. Sebagian besar pedagang kaki lima pada mulanya melakukan kegiatan dalam skala kecil dengan modal yang terbatas, namun tidak sedikit dari mereka akhirnya berhasil sehingga berkembang hampir mendekati sektor formal. Perkembangan usaha ini selanjutnya diikuti dengan 
kebutuhan tenaga kerja. Oleh karenanya tidak sedikit tenaga kerja yang terserap dalam kegiatan usaha ini.

Berdasarkan uraian tersebut pedagang kaki lima dari sisi ekonomi memiliki dampak positif yang meliputi, (1) peningkatan jumlah barang dan jasa yang menyebabkan semakin meningkatnya pendapatan daerah, (2) pedagang kaki lima dapat menyerap tenaga kerja khususnya tenaga kerja yang tidak memiliki ketrampilan dan keahlian, (3) peningkatan pendapatan masyarakat dan (4) berpengaruh terhadap perkembangan industri hilir dan hulu.

Tujuan dari penelitian ini adalah untuk mengetahui dampak pedagang kaki lima terhadap perekonomian Kota Bogor, yang meliputi:

1. Kontribusi pedagang kaki lima terhadap multiplier output di Kota Bogor.

2. Kontribusi pedagang kaki lima terhadap multiplier pendapatan di Kota Bogor.

3. Kontribusi pedangan kaki lima terhadap multiplier penyerapan tenaga kerja di Kota Bogor.

4. Keterkaitan pedagang kaki lima dengan industri hilir dan hulu di Kota Bogor

Hasil penelitian sebelumnya yang dilakukan oleh Ningrum (2015) menemukan bahwa sektor informal yang ada di Indonesia memiliki peran yang sangat penting dalam perekonomian Indonesia, terutama dalam hal penyerapan tenaga kerja.

Sebagai sektor yang eksistensinya tidak terbantahkan dalam ekonomi perkotaan, sektor informal selain menjadi fenomena yang menarik untuk dikaji lebih jauh dengan pendekatan berbagai disiplin ilmu, namun sektor informal juga menyimpan permasalahan dan potensinya sendiri. Sebagai sektor yang sangat bebas untuk dimasuki oleh setiap orang, sektor informal menjadi katup pengaman sosial dalam sebuah negara (Prasetya, 2016). Artinya, jika sektor ini dikelola dengan baik, maka berbagai persoalan sosial khususnya di perkotaan bisa diminimalisir. Kemampuan menyerap tenaga kerja dengan proporsi yang fenomenal serta ikut menyelamatkan perekonomian negara, dalam waktu bersamaan ternyata tidak diimbangi dengan perlakuan yang adil oleh pemerintah (Mus Mualim,Bin Raudha A H, 2009).

\section{METODOLOGI}

Kajian ini menggunakan data sekunder dan primer. Data sekunder dengan menggunakan data Bappeda, BPS dan data Survai Ekonomi (SE), kajian ini merupakan analisis terhadap jumlah, persentase, pertumbuhan rata-rata per tahun, analisis pekerja menurut lapangan pekerjaan dan menurut jenis pekerjaan sektor informal.

Data primer diperoleh melalui wawancara dengan pihak-pihak terkait diantaranya :

1. Perangkat Pemerintah Kota Bogor yang terkait dengan permasalahan sektor informal seperti: Bappeda, Dinas koperasi, industri dan perdagangan, Satpol PP, Dinas Perekonomian.

2. Para pedagang kaki lima.

3. Asosiasi/paguyuban pedagang kaki lima.

4. Akademisi.

5. Lembaga Sosial Masyarakat (LSM) yang bergerak dalam bidang advokasi dan pemberdayaan sektor informal.

6. Masyarakat atau penerima manfaat.

Metode sampling yang digunakan dalam penelitian ini adalah Purposive Sampling, sampel diambil dengan maksud tertentu berdasarkan kriteria yang ditentukan. Data yang digunakan adalah hasil Survai Ekonomi 2015 yang diterbitkan secara resmi Badan Pusat Statistik (BPS) Kota Bogor.

Teknik analisis yang digunakan dalam penelitian ini adalah tabel InputOutput (IO). Analisis dengan tabel IO ini dapat memberikan informasi mengenai angka pengganda output (output 
multiplier), angka pengganda pendapatan (income multiplier), angka pengganda kesempatan kerja (employment multiplier), keterkaitan ke depan (forward linkages) dan keterkaitan ke belakang (backward linkages).

Namun pada umumnya analisis dengan tabel IO ini hanya memasukkan sektor-sektor formal saja. Oleh sebab itu dalam penelitian ini akan menginternalisasikan kegiatan sektor informal ke dalam tabel Input-Output (disimbolkan dengan $\mathrm{IO}^{*}$ ) dan kemudian membandingkan hasil perhitungan dengan IO dan IO* untuk melihat dampak kehadiran sektor informal

\section{Pengertian Input-Output}

Tabel Input-Output adalah suatu uraian statistik dalam bentuk matriks baris dan kolom yang menggambarkan transaksi barang dan jasa serta keterkaitan antara suatu sektor dengan sektor lainnya. Besarnya ketergantungan suatu sektor tertentu terhadap sektor yang lain ditentukan oleh input yang digunakan dalam proses produksi maupun besarnya output yang dialokasikan untuk memenuhi permintaan antara dan permintaan akhir. Dengan demikian pengembangan suatu sektor tidak akan tercapai apabila tidak di dukung oleh sektor lain.

2. Kegunaan Tabel Input-Output

Model IO dapat memberikan gambaran menyeluruh tentang:

a. Struktur perekonomian nasional atau regional yang mencakup struktur output dan nilai tambah masing-masing sektor.

b. Struktur input antara, yaitu penggunaan berbagai barang dan jasa oleh sektor-sektor produksi. c. Struktur penyediaan barang dan jasa baik berupa produksi dalam negeri maupun barang-barang yang berskala impor.

d. Struktur permintaan barang dan jasa, baik permintaan antara oleh sektor-sektor produksi maupun permintaan akhir untuk konsumsi, investasi dan ekspor.

Melihat gambaran di atas, hal ini berarti bahwa model IO akan memberikan beberapa keuntungan atau kegunaan, antara lain:

a. Dapat memberikan deskripsi yang detail tentang perekonomian nasional ataupun regional dengan menguantikasikan ketergantungan antarsektor dan asal (sumber) dari ekspor dan impor.

b. Untuk suatu perangkat permintaan akhir dapat ditentukan besaran output dari setiap sektor dan kebutuhannya akan faktor produksi dan sumber daya.

c. Dampak perubahan permintaan terhadap perekonomian baik yang disebabkan oleh sektor swasta ataupun pemerintah dapat ditelusuri dan diramalkan secara terperinci.

d. Perubahan-perubahan teknologi dan harga relatif dapat diintegrasikan ke dalam model melalui perubahan koefisien teknik.

Melalui model IO dapat ditelusuri kemana saja output dari suatu sektor didistribusikan dan input apa saja yang digunakan oleh sektor tersebut. Dengan memodifikasi model IO kita membentuk alur distribusi dengan terbentuknya suatu model IO secara sederhana (khususnya jika dilihat dari sisi permintaan) yang digambarkan sebagai berikut: 


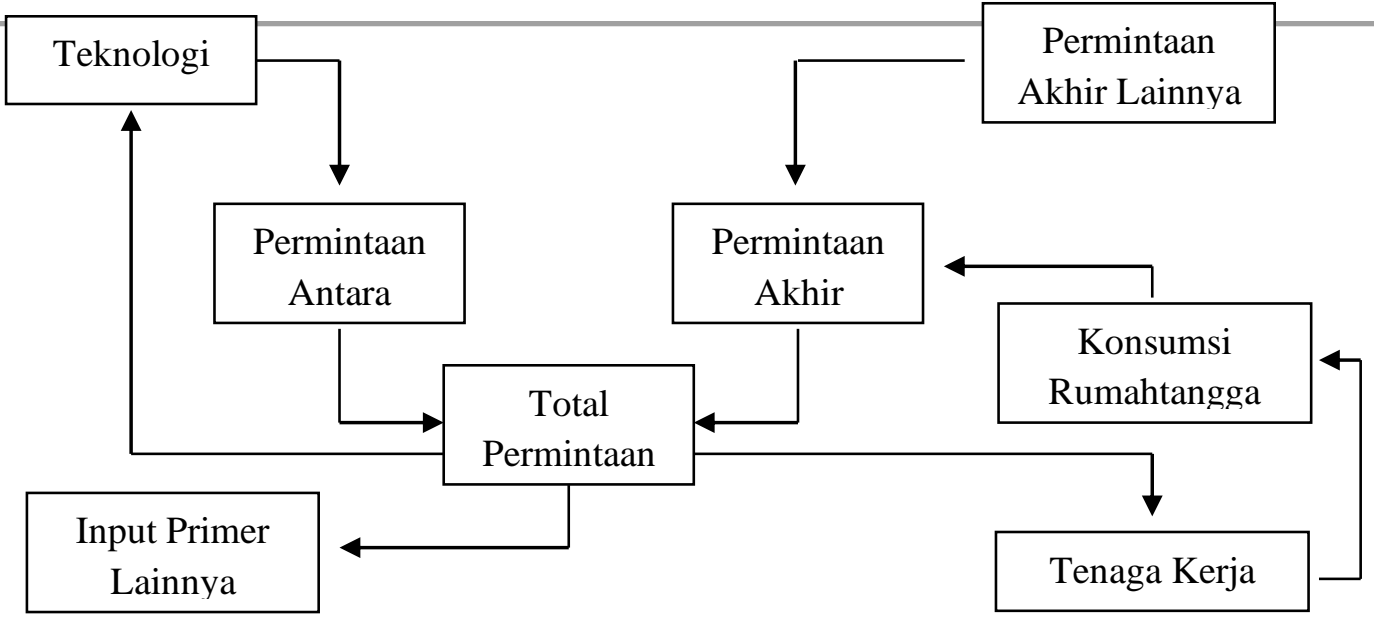

Gambar 1. Model Sederhana Input-Output

Gambar 1. di atas menjelaskan bahwa output dari sektor produksi didistribusikan kepada dua konsumen, yaitu pertama konsumen yang menggunakan output tersebut sebagai input untuk proses produksi lanjutan (konsumen ini disebut produsen) dan kedua konsumen yang menggunakan output tersebut untuk dikonsumsi langsung (konsumen akhir, yaitu rumah tangga, pemerintah, swasta dan konsumen luar negeri). Bagi konsumen pertama, output suatu sektor merupakan input antara dalam proses produksinya, sedangkan pada konsumen kedua, ouputnya merupakan permintaan akhir.

Dalam kaitannya dengan input, dapat dilihat adanya perpindahan barang antarsektor. Namun demikian input yang digunakan dalam suatu proses produksi bukan hanya berupa input antara saja, tetapi ada input-input lainnya yaitu faktor produksi tenaga kerja, modal, tanah dan lain sebagainya di mana kesemuanya ini digolongkan sebagai input primer. Dalam model IO input primer ini direfleksikan melalui upah dan gaji, surplus usaha, pajak tak langsung dan subsidi. Selain input yang berasal dari dalam negeri ada juga input yang berasal dari luar negeri. Oleh karena 104 itu model IO juga memasukkan komoditas impor dalam distribusi inputnya.

\section{Dasar Teori Input-Output}

Output yang dihasilkan oleh suatu sektor i didistribusikan ke dua pemakai, yaitu sektor produksi dan pemakain akhir. Dalam input antara dapat terjadi arus perpindahan barang antar sektor misalnya sektor i ke sektor $\mathrm{j}$ dan dapat pula terjadi perpindahan dalam sektor itu sendiri (perpindahan intrasektor), perpindahan terjadi dari sektor i ke sektor j jika i = j. Dimisalkan nilai uang arus barang dari sektor i ke sektor $\mathrm{j}$ dinotasikan $\mathrm{z}_{\mathrm{ij}}$, kemudian total output sektor i dinotasikan $\mathrm{X}_{\mathrm{i}}$, sedangkan total permintaan akhir dari sektor i dinotasikan $\mathrm{Y}_{\mathrm{i}}$, maka dapat dituliskan total output dari sektor i sebagai berikut :

$\mathrm{X}_{\mathrm{i}}=\mathrm{Z}_{\mathrm{i} 1}+\mathrm{Z}_{\mathrm{i} 2}+\mathrm{Z}_{\mathrm{i} 3}+\ldots+\mathrm{Z}_{\text {in }}+\mathrm{Y}_{1}$

Oleh karena dalam perekonomian terdapat $\mathrm{n}$ sektor produksi, maka secara keseluruhan dapat dituliskan total output semua sektor sebagai berikut :

$\mathrm{X}_{1}=\mathrm{Z}_{11}+\mathrm{z}_{12}+\mathrm{z}_{13}+\ldots+\mathrm{z}_{1 \mathrm{n}}+\mathrm{Y}_{\mathrm{i}}$

$X_{2}=Z_{21}+z_{22}+Z_{23}+\ldots+z_{2 n}+Y_{2}$

$\mathrm{X}_{\mathrm{i}}=\mathrm{Z}_{\mathrm{i} 1}+\mathrm{Z}_{\mathrm{i} 2}+\mathrm{Z}_{\mathrm{i} 3}+\ldots+\mathrm{Z}_{\mathrm{in}}+\mathrm{Y}_{\mathrm{i}}$

$X_{n}=z_{n 1}+z_{n 2}+z_{n} 3+\ldots+z_{n n}+Y_{n}$

Jika dinotasikan dalam bentuk tabel matriks, untuk setiap kolom dapat dituliskan sulutuz 11 tor kolom yang berisikan : 
Misalkan dalam suatu perekonomian terdapat tiga sektor produksi saja, yaitu sektor 1, 2 dan 3, berdasarkan persamaan di atas dapat dibuat sebuah kerangka dasar Tabel IO berikut:

Tabel 1. Model Input-Output Untuk Tiga Sektor

\begin{tabular}{|c|c|c|c|c|c|c|c|c|c|}
\hline \multirow{2}{*}{\multicolumn{2}{|c|}{ Input $\quad$ Output }} & \multicolumn{3}{|c|}{ Sektor Produksi } & \multicolumn{4}{|c|}{ Permintaan Akhir } & \multirow{2}{*}{$\begin{array}{c}\begin{array}{c}\text { Total } \\
\text { Output }\end{array} \\
\text { X }\end{array}$} \\
\hline & & 1 & 2 & 3 & $\mathbf{C}$ & I & $\mathbf{G}$ & $\mathbf{E}$ & \\
\hline \multirow[t]{3}{*}{ Sektor Produksi } & 1 & $\mathrm{z}_{11}$ & $\mathrm{Z}_{12}$ & $\mathrm{Z}_{13}$ & $\mathrm{C}_{1}$ & $\mathrm{I}_{1}$ & $\mathrm{G}_{1}$ & $\mathrm{E}_{1}$ & $\mathrm{X}_{1}$ \\
\hline & 2 & $\mathrm{Z}_{21}$ & $\mathrm{Z}_{22}$ & $\mathrm{Z}_{23}$ & $\mathrm{C}_{2}$ & $\mathrm{I}_{2}$ & $\mathrm{G}_{2}$ & $\mathrm{E}_{2}$ & $\mathrm{X}_{2}$ \\
\hline & 3 & $\mathrm{Z}_{31}$ & $\mathrm{Z}_{32}$ & $\mathrm{Z}_{33}$ & $\mathrm{C}_{3}$ & $\mathrm{I}_{3}$ & $\mathrm{G}_{3}$ & $\mathrm{E}_{3}$ & $\mathrm{X}_{3}$ \\
\hline Input Primer & $\mathrm{V}$ & $\mathrm{V}_{1}$ & $\mathrm{~V}_{2}$ & $\mathrm{~V}_{3}$ & $\mathrm{~V}_{\mathrm{C}}$ & $\mathrm{V}_{\mathrm{I}}$ & $\mathrm{V}_{\mathrm{G}}$ & $\mathrm{V}_{\mathrm{E}}$ & $\mathrm{V}$ \\
\hline Impor & $\mathrm{M}$ & M1 & M2 & M3 & $\mathrm{M}_{\mathrm{C}}$ & $\mathrm{M}_{\mathrm{I}}$ & $\mathrm{M}_{\mathrm{G}}$ & $\mathrm{M}_{\mathrm{E}}$ & $\mathrm{M}$ \\
\hline Total Input & X & $\mathrm{X}_{1}$ & $X_{2}$ & $\mathrm{X}_{3}$ & $\mathrm{C}$ & I & $\mathrm{G}$ & $E$ & $\mathrm{X}$ \\
\hline
\end{tabular}

Tabel 1. di atas menunjukkan transaksi antar komponen suatu perekonomian pada satu titik waktu. Diasumsikan bahwa perekonomian terdiri dari tiga sektor produksi, yaitu sektor 1, 2 dan 3, komponen permintaan akhir terdiri dari empat, yaitu konsumsi rumah tangga (C), investasi perusahaan (I), pengeluaran pemerintah $(\mathrm{G})$ dan ekspor luar negeri (E), satu faktor produksi misalkan tenaga kerja dengan balas jasa upah (V), selain itu sektor-sektor produksi maupun pengguna akhir dapat juga membeli barang dari luar negeri dalam bentuk impor (M). Terdapat tiga matriks dasar yang dapat dilihat dalam tabel di atas, yaitu :

a. Matriks $\mathrm{Z}$ atau matriks transaksi input antara

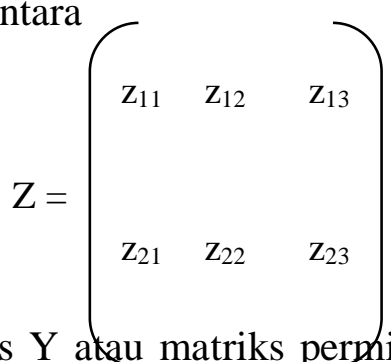

b. Matriks Y atau matriks pernintaan akhir yang terdiri dari konsumsi rumah tangga (C), investasi perusahaan (I), pengeluaran pemerintah (G) dan ekspor (E)

$$
\mathrm{Y}=\left(\begin{array}{cccc}
\mathrm{C}_{1} & \mathrm{I}_{1} & \mathrm{G}_{1} & \mathrm{E}_{1} \\
\mathrm{C}_{2} & \mathrm{I}_{2} & \mathrm{G}_{2} & \mathrm{E}_{2}
\end{array}\right)
$$

c. Matriks V atau matriks input primer yang terdiri dari upah atau gaji (W), surplus usaha (S), penyusutan (D) dan pajak tidak langsung/minus subsidi (T).

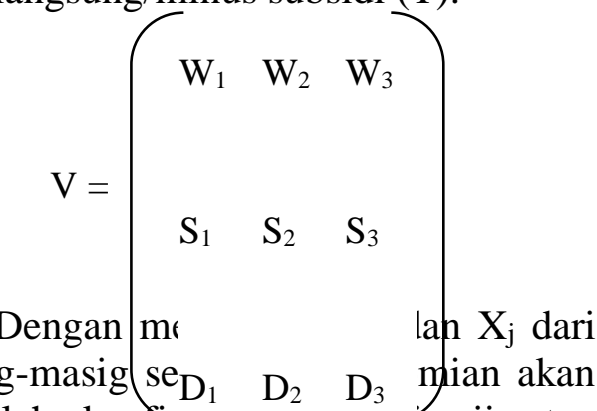

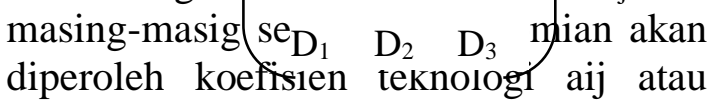
yang disebut dengan koefisien inputoutput atau koefisien input langsung seperti : 
Persamaan tersebut menunjukkan bahwa seluruh koefisien $a_{i j}$ tidak lain mencerminkan hubungan antara output sektor-j dengan input sektor-i dan hubungan keduanya sifatnya tetap. Koefisien ini menunjukkan jumlah input sektor-i yang dibutuhkan untuk menghasilkan satu unit output sektor-j. Jika terdapat $n$ sektor di dalam perekonomian, maka diperoleh sebanyak $\mathrm{n}$ x $\mathrm{n}$ koefisien $\mathrm{a}_{\mathrm{ij}}$.

Seluruh koefisien $a_{i j}$ tersebut jika dinyatakan dalam matriks akan menjadi matriks teknologi sebagai berikut :

$$
A=\left(\begin{array}{lll}
a_{11} & a_{12} & a_{13} \\
a_{21} & a_{22} & a_{23}
\end{array}\right)
$$

Setelah mendapatkan koefisien teknologi $\mathrm{a}_{\mathrm{ij}}$ dan melalui manipulasi aljabar menghasilkan persamaan :

$X_{1}=a_{11} X_{1}+a_{12} X_{2}+a_{13} X_{3}+. .+a_{1 n} X_{n}+Y_{1}$

$X_{2}=a_{21} X_{1}+a_{22} X_{2}+a_{23} X_{3}+\ldots+a_{2 n} X_{n}+Y_{2}$

$X_{n}=a_{n 1} X_{1}+a_{n 2} X_{2}+a_{n 3} X_{3}+. .+a_{n n} X_{n}+Y_{n}$

atau disederhanakan menjadi :

$\left(1-a_{11}\right) X_{1}-a_{12} X_{2}-a_{13} X_{3}-\ldots-a_{1 n} X_{n}==Y_{1}$ $-a_{21} X_{1}+\left(1-a_{22}\right) X_{2}-a_{23} X_{3}-\ldots-a_{2 n} X_{n}=Y_{2}$ $-a_{n 1} X_{1}-a_{n 2} X_{2}-a_{n} X_{3}-\ldots+\left(1-a_{2 n}\right) X_{n}=Y_{n}$

Sistem persamaan tersebut dapat dituliskan dalam notasi matriks sederhana sebagai berikut :

$$
(\mathrm{I}-\mathrm{A}) \mathrm{X}=\mathrm{Y}
$$

Di mana I adalah matriks identitas yang berukuran $\mathrm{n} \times \mathrm{n}$, kemudian $\mathrm{A}$ adalah matriks koefisien input, sedangkan $\mathrm{X}$ dan $\mathrm{Y}$ masing-masing menunjukkan vektor kolom matriks output dan permintaan akhir. Jika terdapat perubahan permintaan akhir dalam perekonomian akan ada perubahan pola pendapatan nasional dan dituliskan:

$$
\begin{aligned}
X & =(I-A)^{-1} Y \\
& =M a Y
\end{aligned}
$$

Matriks Ma adalah (I - A $)^{-1}$ yang dikenal dengan nama matriks invers Leontief. Elemen matriks ini dinotasikan dengan $\mathrm{a}_{\mathrm{ij}}$ dan mencerminkan efek langsung dan tidak langsung dari perubahan permintaan akhir terhadap output sektor-sektor di dalam perekonomian. Permintaan akhir tersebut adalah variabel yang eksogen sifatnya. Salah satu komponennya adalah pengeluaran pemerintah yang besarnya sepenuhnya diatur oleh pemerintah itu sendiri.Sementara itu komponenkomponen lain dari permintaan akhir tersebut (konsumsi rumah tangga, investasi perusahaan dan ekspor) adalah variabel-variabel yang besarnya dapat dipengaruhi oleh pemerintah dengan berbagai kebijakannya. Dalam konteks ini maka permintaan akhir dapat menjadi alat kebijakan pemerintah. Oleh sebab itu dengan target tingkat pertumbuhan ekonomi tertentu, pemerintah dapat memilih instruyen mana yang akan digunakan untuk mendorong permintaan akhir tersebut dan sekaligus juga melihat dampak dari tingkat pertumbuhan tersebut pada output sektor-sektor tertentu di dalam perekonomian.

5. Keterkaitan Antarsektor dalam Model Input-Output

Model IO dapat digunakan sebagai alat pengambil keputusan dalam merencanakan pembangunan sektoral. Dari hasil analisis IO dapat diputuskan sektor-sektor mana saja yang dijadikan sebagai leading sector atau sektor pimpinan dalam pembangunan ekonomi. Dengan memfokuskan pada sektor-sektor yang menjadi pimpinan maka target pertumbuhan ekonomi yang diharapkan dapat dicapai dengan lebih baik. Suatu sektor yan terindikasi 
sebagai pimpinan dianggap memiliki kemampuan daya sebar dan kepekaan yang sangat tinggi dalam suatu perekonomian, sehingga efek yang diberikannya bersifat ganda. Di satu sisi sektor tersebut dapat mendorong permintaan agregat (aggregate demand) yang lebih tinggi dan di sisi lain dapat meningkatkan penawaran agregat (aggregate supply) untuk pemenuhan kebutuhan domestik.

Adanya penggunaan input antara yang berasal dari output sektor produksi lain dan penggunaan input primer seperti tenaga kerja dan modal membuat suatu sektor produksi menjadi terintegrasi dengan sektorsektor lainnya dalam perekonomian. Hubungan ini merupakan hubungan saling ktergantungan satu dengan lainnya, di mana output dari suatu sektor produksi merupakan input bagi sektor produksi lainnya. Oleh sebab itu perubahan output suatu sektor produksi akan mempengaruhi output sektor produksi lainnya. Rincian keterkaitan antar sektor produksi ini antara lain keterkaitan langsung ke belakang dan ke depan, daya sebar ke depan dan ke belakang.

Keterkaitan antar sektor merupakan salah satu syarat yang harus dimiliki oleh growth pole dalam perkembangan ekonomi yang lebih mengacu pada suatu sektor yang bisa menyebar dalam berbagai aktivitas sektor produksi sehingga mampu menggerakkan ekonomi secara keseluruhan. Sektor semacam ini umumnya memiliki ciri-ciri antara lain (Arsyad, 1999) :

a. Perkembangannya relatif cepat.

a. Industrinya relatif besar untuk memberikan dampak langsung dan tidak langsung. b. Memiliki keterkaitan tinggi antar industri

Model IO dapat digunakan untuk melihat sektor-sektor apa saja yang dapat menjadi sektor pemimpin dalam pembangunan. Sektor-sektor tersebut dapat dideteksi dengan empat cara, yaitu:

a. Suatu sektor dianggap sebagai sektor kunci apabila mempunyai kaitan ke belakang (backward linkage) dan kaitan ke depan (forward linkage) yang relatif tinggi.

b. Suatu sektor dianggap sebagai sektor kunci apabila menghasilkan output bruto yang relatif tinggi, sehingga mampu mempertahankan final demand yang relatif tinggi pula.

c. Suatu sektor dianggap sebagai sektor kunci jika mampu menghasilkan penerimaan bersih devisa yang relatif tinggi.

d. Suatu sektor dianggap sebagai sektor kunci jika mampu menciptakan lapangan kerja yang relatif tinggi.

Keterkaitan ke belakang di suatu sektor diperoleh dengan menjumlahkan secara kolom matriks input A dengan formlasi :

$$
\mathrm{BL}_{\mathrm{j}}={ }_{\sum}^{\mathrm{n}} \frac{\mathrm{X}_{\mathrm{ij}}}{\mathrm{X}_{\mathrm{j}}}={ }_{\sum}^{\mathrm{n}} \mathrm{a}_{\mathrm{ij}}
$$

Sedangkan untuk memperoleh keterkaitan ke depan dilakukan dengan cara yang sama, namun penjumlahan dilakukan secara baris dengan formulasi :

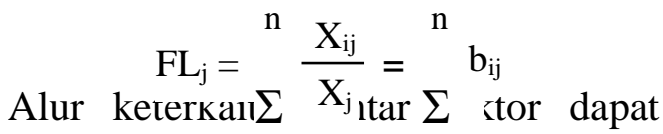
digambarkan sevagai berıкut : Depan 
Gambar 2. Alur Keterkaitan Antar Sektor Dalam Perekonomian

Dimisalkan perekonomian terdiri dari tiga sektor, yaitu sektor 1, sektor 2 dan sektor 3. Sektor 2 membutuhkan output dari sektor 1 sebagai faktor produksinya, sedangkan sektor 3 membutuhkan input yang berasal dari output sektor 2. Oleh karena sektor 2 membeli output dari sektor 1 dalam proses produksinya, maka dapat dikatakan sektor 2 memiliki keterkaitan ke belakang secara langsung dengan sektor 1. Namun di sisi lain output sektor 2 dijual kepada sektor 3 yang hal ini berarti bahwa sektor 2 memiliki keterkaitan ke depan secara lansung dengan sektor 3. Bagi sektor 3, karena outputnya dibeli oleh sektor 2 sementara sektor 2 membeli output sektor 1 sebagai inputnya, maka dapat dikatakan dari rangkaian keterkaitan ini sektor 3 memiliki keterkaitan ke belakang secara tidak langsung dengan sektor 1. Dengan demikian untuk sektor 1, karena outputnya dijual kepada sektor 2, sementara output sektor 2 dijual kepada sektor 3, maka dapat dikatakan bahwa sektor 1 memiliki keterkaitan ke depan secara tidak langsung dengan sektor 3 (Daryanto dan Yundy, 2010).

Dua jenis ukuran indeks untuk melihat keterkaitan ke depan dan ke belakang dari suatu sektor dalam perekonomian , yaitu melalui 108 kemampuan penyebaran (power of dispersion) dan kepekaan penyebaran (sensitivity of dispersion). Dengan dua indeks ini kita dapat melakukan perbandingan besarnya derajat keterkaitan antarsektor, yang nantinya bisa ditentukan sektor-sektor mana saja yang dapat dijadikan sebagai sektor kunci atau sektor pemimpin dalam pembangunan ekonomi.

6. Model Input-Output Regional

Analisis input-ouput untuk daerah memiliki struktur yang sama dengan struktur analisis input-ouput perekonomian nasional. Input-ouput daerah dengan koefisien regional. Koefisien regional tersebut diperoleh benar-benar dari daerah yang bersangkutan. Dengan kata lain metode ini membuat tabel IO regional untuk daerah yang dianalisis. Caranya adalah dengan melakukan survai kepada sektorsektor produksi di daerah tersebut. Dengan demikian diperoleh suatu tabel IO yang memang mencerminkan situasi daerah tersebut.

\section{HASIL DAN PEMBAHASAN}

\section{Dampak Pedagang Kaki Lima Terhadap Perekonomian Kota Bogor}

Sektor formal dan informal merupakan penggerak perekonomian di Kota Bogor. Kedua sektor ini memberikan kontribusi yang berbeda bagi perekonomian. Pedagang kaki lima 
merupakan salah satu jenis sektor informal yang banyak di Kota Bogor, telah mampu memberikan kontribusi besar terhadap perekononmian Kota Bogor, antara lain mempermudah masyarakat memperoleh kebutuhan, meningkatkan perekonomian (pendapatan) masyarakat kecil, mengurangi pengangguran dan meningkatkan pendapatan daerah dan produk domestik bruto.

Pedagang kaki lima dapat mengurangi pengangguran karena sektor ini banyak menyerap tenaga kerja. Hal ini dapat terjadi karena pedagang kaki lima lebih mudah dimasuki oleh para pencari kerja dibandingkan sektor formal. Tenaga kerja dalam sektor ini tidak membutuhkan spesifikasi khusus seperti dalam sektor formal, hanya berbekal kemauan bekerja saja sudah dapat memasuki sektor ini. Selain kontribusi terhadap penyerapan tenaga kerja pedagang kaki lima juga memiliki kontribusi terhadap pendapatan daerah. Hal ini terlihat dari kemampuan pedagang kaki lima dalam memenuhi kebutuhan masyarakat khususnya masyarakat menengah ke bawah yang merupakan mayoritas di daerah. Melihat fakta tersebut perlu kiranya dilakukan pengkajian seberapa besar kontribusi pedagang kaki lima terhadap perekonomian khususnya dalam hal kontribusinya terhadap pendapatan daerah dan penyerapan tenaga kerja di Kota Bogor.

Penelitian ini menggunakan tabel transaksi input-output Kota Bogor sebagai dasar dan telah diagregasi menjadi lima sektor. Untuk mengetahui kontribusi pedagang kaki lima terhadap perekonomian Kota Bogor dilakukan dengan menggunakan analisis inputoutput dengan dua versi, yaitu analisis input output sebelum menginternalisasikan pedagang kaki lima (IO) dan analisis input-output yang setelah menginternalisasikan pedagang kaki lima (IO*). Analisis yang tidak menginternalisasikan pedagang kaki lima (IO) ditunjukkan tabel berikut:

Tabel 2. Input-Output 5x5 Sebelum Menginternalkan Pedagang Kaki Lima (dalam miliar rupiah)

\begin{tabular}{|c|r|r|r|r|r|r|r|r|}
\hline Sektor & \multicolumn{1}{|c|}{$\mathbf{1}$} & \multicolumn{1}{|c|}{$\mathbf{2}$} & \multicolumn{1}{|c|}{$\mathbf{3}$} & \multicolumn{1}{|c|}{$\mathbf{4}$} & \multicolumn{1}{c|}{$\mathbf{5}$} & \multicolumn{1}{c|}{$\mathbf{1 8 0}$} & \multicolumn{1}{c|}{ F } & \multicolumn{1}{c|}{ TK } \\
\hline $\mathbf{1}$ & 6793 & 3127 & 735 & 1 & 73 & 10729 & 804838 & 815567 \\
\hline $\mathbf{2}$ & 153037 & 845908 & 220928 & 31690 & 233525 & 1485088 & 2042638 & 3527726 \\
\hline $\mathbf{3}$ & 406319 & 609164 & 247819 & 36736 & 19043 & 1319081 & 1887542 & 3206623 \\
\hline $\mathbf{4}$ & 30428 & 249406 & 74515 & 516378 & 73591 & 944318 & 790475 & 1734793 \\
\hline $\mathbf{5}$ & 130949 & 79286 & 40723 & 193212 & 237279 & 681449 & 182537 & 863986 \\
\hline $\mathbf{1 9 0}$ & 727526 & 1786891 & 584720 & 778017 & 563511 & & & \\
\hline $\mathbf{V}$ & 88041 & 1740835 & 2621903 & 956776 & 300475 & & & \\
\hline $\mathbf{X}$ & 815567 & 3527726 & 3206623 & 1734793 & 863986 & & & \\
\hline
\end{tabular}

Sumber : data diolah

Keterangan :

- 1 = Pertanian, Pertambangan, Penggalian

- 2 = Industri Pengolahan

- 3 = Listrik, Gas, Air bersih, Bangunan

- 4 = Perdagangan, Hotel dan Restoran, Pengangkutan dan Komunikasi

- 5 = Keuangan, Perbankan, Jasa-jasa

- 190 = jumlah biaya antara

- $\mathrm{V}=$ nilai tambah bruto

- X = Output = Jmlah biaya antara (190) + Nilai tambah bruto (V)

- $180=$ Jumlah permintaan antara

- $\mathrm{F}=$ jumlah permintaan akhir

- $\mathrm{TK}=$ total konsumsi $=$ permintaan antara $(180)+$ permintaan akhir $(\mathrm{F})$ 
Selanjutnya analisis input-output yang menginternalisasikan pedagang kaki lima (IO*) dilakukan dengan menggunakan metode RAS. Tujuan dikembangkan dan digunakan metode ini adalah untuk menghasilkan matriks teknologi pada tahun tertentu dengan menggunakan matriks teknologi yang telah ada, tanpa harus melakukan survai secara detail kembali.

Pada dasarnya RAS adalah sebuah nama rumus matriks di mana $\mathrm{R}$ dan $\mathrm{S}$ adalah matriks diagonal berukuran $\mathrm{n} \times \mathrm{n}$ dan A merupakan matriks berukuran $\mathrm{n} x$ $\mathrm{n}$ yang menunjukkan banyaknya sektor industri. Jika ingin menaksir elemen matriks A pada periode $\mathrm{t}$ (atau At) serta diketahui elemen matriks A pada periode $\mathrm{t}=0$ (atau A (0)), maka A(t) dapat ditaksir dengan menggunakan formulasi : $\mathrm{A}(\mathrm{t})=\mathrm{R} \cdot \mathrm{A}(0) \cdot \mathrm{S}$

Elemen matriks A disebut sebagai koefisien teknologi (koefisien input). Tingkat perubahan koefisien teknologi pada dua periode yang berbeda diwakili oleh elemen matriks $\mathrm{R}$ dan $\mathrm{S}$. Elemen matriks diagonal $\mathrm{R}$ mewakili efek substitusi teknologi yang diukur melalui penambahan jumlah permintaan antara tiap output sektor-sektor industri. Kemudian eleman matriks diagonal $\mathrm{S}$ menunjukkan efek perubahan jumlah input pada setiap sektor industri.

Salah satu penyebab digunakannya metode RAS ini disebabkan karena umumnya sektor informal tidak tercatat dalam instrumen pencatatan kegiatan ekonomi. Namun demikian pedagang kaki lima memiliki keterkaitan dengan sektor formal dan memiliki kontribusi terhadap kegiatan ekonomi daerah. Untuk keperluaan analisis ini, maka sektor informal terbagi menjadi lima kelompok yang disesuaikan dengan sektor formal, yaitu (1) pertanian, pertambangan dan penggalian, (2) industri pengolahan, (3) listrik, gas, air bersih dan bangunan, (4) perdagangan, 110 hotel dan restoran, pengangkutan dan komunikasi dan (5) keuangan, perbankan dan jasa-jasa.
Berdasarkan hasil wawancara pada beberapa pihak yang terkait dan pedagang kaki lima dapat disimpulkan bahwa pedagang kaki lima memiliki keterkaitan dengan sektor formal, dimana dari perkiraan diketahui bahwa pedagang kaki lima menyerap 26 persen output sektor formal dengan rincian sebagai berikut :

1. Pertanian, pertambangan dan penggalian sebesar tiga persen

2. Industri pengolahan sebesar sepuluh persen

3. Listrik, gas, air bersih dan bangunan sebesar lima persen

4. Perdagangan, hotel dan restoran, pengangkutan dan komunikasi sebesar empat persen

5. Keuangan, perbankan dan jasa-jasa sebesar empat persen

Nilai di atas dapat dijelaskan bahwa pedagang kaki lima memiliki kontribusi ke output antara sektor pertanian, pertambangan dan penggalian sebesar 3 persen yang berasal dari 26 persen dikalikan dengan pangsa output antara sektor pertanian, pertambangan dan penggalian. Kegiatan pedagang kaki lima memberikan kontribusi terbesar terhadap penyerapan output sektor formal adalah industri pengolahan yaitu sebesar 10 persen. Untuk sektor listrik, gas, air bersih bangunan pedagang kaki lima memberikan kontribusi sebesar lima persen terhadap penyerapan sektor formal. Sedangkan sektor perdagangan, hotel dan restoran, pengangkutan dan komunikasi serta sektor keuangan, perbankan dan jasa-jasa masing-masing memberikan kontribusi terhadap penyerapan output sektor formal sebesar empat persen.

Sebagian output yang dihasilkan oleh sektor informal ada yang langsung dikonsumsi tetapi ada juga digunakan sebagai bahan dasar untuk sektor formal. Kontribusi output sektor informal sebagai barang akhir (final demand) umumnya lebih kecil dibandingkan dengan nilai output sektor formal. Perkiraan kontribusi output kegiatan sektor informal terhadap 
total barang/permintaan akhir adalah sebesar 22 persen, dengan rincian sebagai berikut :

1. Pertanian, pertambangan dan penggalian sebesar persen persen

2. Industri pengolahan sebesar sembilan persen

3. Listrik, gas, air bersih dan bangunan sebesar empat persen

4. Perdagangan, hotel dan restoran, pengangkutan dan komunikasi sebesar tiga persen

5. Keuangan, perbankan dan jasa-jasa sebesar tiga persen

Selain menggunakan output dari sektor formal, pedagang kaki lima juga memberikan dampak yang positif bagi sektor formal berupa penyediaan input bagi proses produksi sektor formal. Diperkirakan sektor informal memberikan kontribusi dalam menyediakan input bagi sektor formal sebesar 25 persen dengan rincian:

1. Pertanian, pertambangan dan penggalian sebesar tiga persen

2. Industri pengolahan sebesar sebelas persen

3. Listrik, gas, air bersih dan bangunan sebesar tiga persen

4. Perdagangan, hotel dan restoran, pengangkutan dan komunikasi sebesar empat persen

5. Keuangan, perbankan dan jasa-jasa sebesar empat persen

Dari perkiraan prosentase kontribusi pedagang kaki lima terhadap output antara, total output dan total biaya input antara di atas serta dengan mengaplikasikan metode RAS, diperoleh tabel input-ouput setelah menginternalisasikan pedagang kaki lima sebagai berikut:

Tabel 3. Input-Output 5x5 Setelah Menginternalkan Pedagang Kaki Lima (dalam triliun rupiah)

\begin{tabular}{|c|r|r|r|r|r|r|r|c|}
\hline Sektor & \multicolumn{1}{|c|}{$\mathbf{1}$} & \multicolumn{1}{|c|}{$\mathbf{2}$} & \multicolumn{1}{c|}{$\mathbf{3}$} & \multicolumn{1}{c|}{$\mathbf{4}$} & \multicolumn{1}{c|}{$\mathbf{5}$} & \multicolumn{1}{c|}{$\mathbf{1 8 0}$} & \multicolumn{1}{c|}{ F } & TK \\
\hline $\mathbf{1}$ & 7009,79 & 3501,33 & 1115,38 & 1,05 & 78,09 & 11705,66 & 828328,35 & 840034,01 \\
\hline $\mathbf{2}$ & 150247,8 & 901147,04 & 318973,8 & 3168973,6 & 237698,47 & 1639754,72 & 2223335,5 & 3863090,5 \\
\hline $\mathbf{3}$ & 428211 & 696603,78 & 384076,7 & 39431,02 & 20806,90 & 1569129,43 & 2034729,6 & 3603859,1 \\
\hline $\mathbf{4}$ & 31159,47 & 277130,55 & 112215,5 & 538567,17 & 781130,87 & 1037203,59 & 757413,37 & 1794616,9 \\
\hline $\mathbf{5}$ & 132723,7 & 87197,41 & 60698,59 & 199450,83 & 249337,08 & 729407,60 & 166133,09 & 895540,69 \\
\hline $\mathbf{1 9 0}$ & 749351,78 & 1965580,1 & 877080,0 & 809137,86 & 586051,44 & & & \\
\hline $\mathbf{V}$ & 90682,23 & 1897510,1 & 2726779,1 & 985479,28 & 309489,25 & & & \\
\hline $\mathbf{X}$ & 840034,01 & 3863090,5 & 3603859,1 & 1794616,9 & 895540,69 & & & \\
\hline
\end{tabular}

Sumber : pengolahan data

Keterangan :

- 1 = Pertanian, Pertambangan, Penggalian

- 2 = Industri Pengolahan

- 3 = Listrik, Gas, Air bersih, Bangunan

- 4 = Perdagangan, Hotel dan Restoran, Pengangkutan dan Komunikasi

- 5 = Keuangan, Perbankan, Jasa-jasa

- 190 = jumlah biaya antara

- $\mathrm{V}$ = nilai tambah bruto

- X = Output = Jmlah biaya antara (190) + Nilai tambah bruto (V)

- $180=$ Jumlah permintaan antara

- $\mathrm{F}=$ jumlah permintaan akhir

- TK = total konsumsi $=$ permintaan antara $(180)+$ permintaan akhir $(\mathrm{F})$

Analisis model input-output pada dasarnya digunakan untuk melihat pengaruh sektor-sektor industri formal terhadap perekonomian suatu negara. Di mana pengaruh ini dapat dilihat dari nilai output yang dihasilkan oleh sektor tersebut. Namun dengan menginternalisasikan pedagang kaki lima ke dalam model input output akan dapat diketahui pula pengaruh pedagang kaki lima terhadap perekonomian Kota Bogor. Hal ini dapat dilihat dari analisa 
input-output dengan membandingkan kinerja perekonomian hasil perhitungan tabel input-output sebelum menginternalkan pedagang kaki lima (IO) dengan tabel input-output yang telah menginternalkan pedagang kaki lima (IO*). Indikator kinerja perekonomian secara makro meliputi angka pengganda output (output multiplier), angka pengganda pendapatan (income multiplier), angka pengganda tenaga kerja (employee multiplier) dan keterikatan antar sektor (linkages) yang akan dijelaskan sebagai berikut :

1. Angka Pengganda Output (Output Multiplier)

Efek pengganda suatu sektor dapat dijelaskan bahwa dengan adanya peningkatan permintaan akhir (final demand) pada suatu sektor akan meningkatkan output sektor itu sendiri dan sektor-sektor lain dalam perekonomian. Peningkatan output terhadap sektor-sektor lain dapat terjadi akibat adanya efek langsung dan efek tidak langsung (hubungan teknis antar sektor) dari peningkatan permintaan akhir. Besarnya kelipatan perubahan output akibat perubahan permintaan akhir suatu sektor inilah yang disebut dengan angka pengganda output. Oleh sebab itu angka pengganda output suatu sektor dapat diartikan sebagai nilai total dari output yang dihasilkan oleh perekonomian yang tercipta akibat adanya perubahan satu unit permintaan akhir.

Besarnya angka pengganda output untuk sektor ke-n di dalam perekonomian dihitung dari penjumlahan kolom ke-n dari matriks kebalikan Leontief untuk perekonomian yang bersangkutan. Berdasarkan hasil perhitungan inputoutput diperoleh angka pengganda output disajikan pada Tabel 4.

Tabel 4. Angka Pengganda Output

\begin{tabular}{|c|l|r|r|r|}
\hline No. & \multicolumn{1}{|c|}{ Sektor } & \multicolumn{1}{|c|}{$\begin{array}{c}\text { Sebelum } \\
\text { Menginternalisasi PKL } \\
\text { (IO) }\end{array}$} & \begin{tabular}{c}
\multicolumn{1}{|c|}{$\begin{array}{c}\text { Setelah } \\
\text { Menginternalisasi } \\
\text { PKL } \\
\text { (IO*) }\end{array}$} \\
Perubahan \\
(persen)
\end{tabular} \\
\hline 1. & $\begin{array}{l}\text { Pertanian, Pertambangan, } \\
\text { Penggalian }\end{array}$ & 11,972 & 12,578 & 5,064 \\
\hline 2. & Industri Pengolahan & 25,485 & 27,056 & 6,162 \\
\hline 3. & $\begin{array}{l}\text { Listrik, Gas, Air bersih, } \\
\text { Bangunan }\end{array}$ & 1,172 & 1,243 & 6,054 \\
\hline 4. & $\begin{array}{l}\text { Perdagangan, Hotel dan Restoran, } \\
\text { Pengangkutan dan Komunikasi }\end{array}$ & 1,725 & 1,740 & 0,854 \\
\hline 5. & Keuangan, Perbankan, Jasa-jasa & 1,952 & 1,988 & 1,867 \\
\hline
\end{tabular}

Sumber : pengolahan data

Interpretasi angka pengganda output tersebut dimisalkan pada pedagang kaki lima pada sektor pertanian, pertambangan dan penggalian, di mana perubahan angka pengganda output setelah menginternalkan pedagang kaki lima adalah sebesar 5,064 yang menginterpretasikan bahwa setiap kenaikan satu rupiah $(\mathrm{Rp} 1,00,-)$ permintaan akhir pada pedagang kaki 112 lima pada sektor pertanian, pertambangan dan penggalian akan menyebabkan kenaikan total output perekonomian Kota Bogor sebesar Rp. 5,064,-. Dengan demikian dapat dikatakan bahwa keberadaan kaki lima di setiap sektor memberikan kontribusi atau pengaruh positif bagi total output perekonomian Kota Bogor.

Dalam analisis tersebut terlihat bahwa perubahan terbesar terjadi pada sektor industri pengolahan, yaitu sebesar 6,162 yang mengartikan bahwa permintaan akhir pedagang kaki lima pada sektor industri pengolahan memberikan kenaikan total output 
perekonomian Kota Bogor yang paling besar dibandingkan dengan sektor lainnya. Hal ini mengindikasikan bahwa pedagang kaki lima pada sektor ini memiliki kontribusi yang paling besar terhadap output perekonomian Kota Bogor. Sedangkan kontribusi terendah diberikan oleh pedagang kaki lima pada sektor perdagangan, hotel dan restoran, pengangkutan dan komunikasi yaitu sebesar 0,854 .

2. Angka Pengganda Pendapatan (Income Multiplier)

Selain meningkatkan jumlah output, perubahan permintaan akhir suatu sektor juga akan meningkatkan pendapatan masyarakat atau rumah tangga. Besarnya pelipatgandaan (multiplier) peningkatan ini dapat dilihat dari angka pengganda pendapatan. Oleh sebab itu yang disebut dengan angka pengganda pendapatan adalah perubahan pendapatan rumah tangga total yang tercipta akibat adanya tambahan satu unit permintaan akhir di suatu sektor. Angka pengganda pendapatan ini disebut sebagai peningkatan permintaan akhir dalam bentuk pendapatan rumah tangga.

Hal ini dapat dijelaskan bahwa jika terdapat perubahan permintaan akhir, maka akan terjadi pula perubahan output yang diproduksi oleh setiap sektor produksi yang terkait dalam perekonomian (dalam hal ini ditunjukkan oleh angka pengganda output). Perubahan jumlah output yang diproduksi tersebut kemudian akan mengubah permintaan tenaga kerja yang dibutuhkan. Tenaga kerja yang digunakan akan mendapatkan balas jasa. Karena balas jasa tenaga kerja tersebut merupakan sumber pendapatan rumah tangga dalam bentuk upah atau gaji, maka perubahan permintaan tenaga kerja sudah pasti akan mempengaruhi pendapatan rumah tangga. Untuk melihat angka pengganda dari hasil analisis inputoutput akan dijelaskan oleh tabel berikut ini:

Tabel 5. Angka Pengganda Pendapatan

\begin{tabular}{|c|l|r|r|r|}
\hline No. & \multicolumn{1}{|c|}{ Sektor } & \multicolumn{1}{|c|}{$\begin{array}{c}\text { Sebelum } \\
\text { Menginternalisasi PKL } \\
\text { (IO) }\end{array}$} & \multicolumn{1}{|c|}{$\begin{array}{c}\text { Sesudah } \\
\text { Menginternalisasi } \\
\text { PKL } \\
\text { (IO*) }\end{array}$} & $\begin{array}{r}\text { Perubahan } \\
\text { (persen) }\end{array}$ \\
\hline 1. & $\begin{array}{l}\text { Pertanian, Pertambangan, } \\
\text { Penggalian }\end{array}$ & 33,686 & 35,301 & 4,793 \\
\hline 2. & Industri Pengolahan & 3,363 & 3,483 & 3,566 \\
\hline 3. & $\begin{array}{l}\text { Listrik, Gas, Air bersih, } \\
\text { Bangunan }\end{array}$ & 1,245 & 1,342 & 7,838 \\
\hline 4. & $\begin{array}{l}\text { Perdagangan, Hotel dan } \\
\text { Restoran, Pengangkutan dan } \\
\text { Komunikasi }\end{array}$ & 1,719 & 1,732 & 0,715 \\
\hline 5. & Keuangan, Perbankan, Jasa-jasa & 1,977 & & \\
\hline
\end{tabular}

Sumber : pengolahan data

Interpretasi angka pengganda pendapatan dapat dimisalkan pada pedagang kaki lima pada industri pertanian, pertambangan dan penggalian, di mana perubahan angka pengganda pendapatan setelah menginternalkan pedagang kaki lima adalah sebesar 4,793 yang menginterpretasikan bahwa setiap kenaikan satu rupiah (Rp 1,00,-) permintaan akhir pada pedagang kaki lima pada sektor pertanian, pertambangan dan penggalian akan menyebabkan kenaikan total pendapatan rumah tangga secara agregat dalam perekonomian Kota Bogor sebesar Rp 4,793,-. Hasil analisis ini menunjukkan bahwa keberadaan pedangan kaki lima pada setiap sektor ekonomi memiliki pengaruh dan kontribusi yang positif terhadap pendapatan rumah tangga.

Berdasarkan hasil analisis juga terlihat bahwa perubahan terbesar setelah 
mengeinternalisasikan pedagang kaki lima terjadi pada sektor listrik, gas, air bersih dan bangunan, yaitu sebesar 7,838 yang mengartikan bahwa permintaan akhir pedagang kaki lima pada sektor ini memberikan kenaikan total pendapatan rumah tangga dalam perekonomian Kota Bogor yang paling besar dibandingkan dengan sektor lainnya. Hal ini mengindikasikan bahwa pedagang kaki lima pada sektor ini memiliki kontribusi yang paling besar terhadap pendapatan rumah tangga di Kota Bogor. Sedangkan kontribusi terendah diberikan oleh pedagang kaki lima pada sektor perdagangan, hotel dan restoran, pengangkutan dan komunikasi yaitu sebesar 0,715 .

3. Angka Pengganda Kesempatan Kerja (Employment Multiplier)

Efek lain adanya peningkatan permintaan akhir adalah perubahan kesempatan kerja sebagai akibat adanya peningkatan produksi. Besarnya efek tersebut dapat diperhitungkan dari angka pengganda kesempatan kerja. Angka pengganda kesempatan kerja merupakan efek total dari perubahan lapangan pekerjaan dalam perekonomian akibat adanya satu unit perubahan permintaan akhir di suatu sektor.

Untuk dapat mengetahui efek dari satu unit perubahan permintaan akhir di suatu sektor produksi terhadap perubahan lapangan pekerjaan di seluruh perekonomian diperlukan jumlah lapangan pekerjaan awal atau jumlah tenaga kerja awal pada masing-masing sektor produksi yang memang telah digunakan untuk melakukan proses produksi selama ini. Data tersebut kemudian digunakan untuk menghitung berapa kontribusi setiap pekerja, secara rata-rata dalam memproduksi output sektornya masing-masing. Tabel yang menunjukkan angka pengganda kesempatan kerja akan disajikan di bawah ini :

Tabel 6. Angka Pengganda Tenaga Kerja

\begin{tabular}{|c|c|c|c|c|}
\hline No. & Sektor & $\begin{array}{c}\text { Sebelum } \\
\text { Menginternalisasi PKL } \\
\text { (IO) }\end{array}$ & $\begin{array}{c}\text { Sesudah } \\
\text { Menginternalisasi PKL } \\
\left(\text { IO }^{*}\right)\end{array}$ & $\begin{array}{c}\text { Perubahan } \\
\text { (persen) }\end{array}$ \\
\hline 1. & $\begin{array}{l}\text { Pertanian, Pertambangan, } \\
\text { Penggalian }\end{array}$ & 29,436 & 30,795 & 4,617 \\
\hline 2. & Industri Pengolahan & 2,352 & 2,412 & 2,521 \\
\hline 3. & $\begin{array}{l}\text { Listrik, Gas, Air bersih, } \\
\text { Bangunan }\end{array}$ & 1,258 & 1,359 & 8,037 \\
\hline 4. & $\begin{array}{l}\text { Perdagangan, Hotel dan } \\
\text { Restoran, Pengangkutan dan } \\
\text { Komunikasi }\end{array}$ & 1,728 & 1,740 & 0,713 \\
\hline 5. & $\begin{array}{l}\text { Keuangan, Perbankan, Jasa- } \\
\text { jasa }\end{array}$ & 2,236 & 2,267 & 1,367 \\
\hline
\end{tabular}

Sumber : pengolahan data

Interpretasi angka pengganda kesempatan kerja dapat dimisalkan pada sektor informal pada industri pengolahan, di mana perubahan angka pengganda pendapatan setelah menginternalkan pedagang kaki lima adalah sebesar 4,617 yang menginterpretasikan bahwa setiap kenaikan satu rupiah $(\mathrm{Rp} 1,00,-)$ 114 permintaan akhir pada pedagang kaki lima pada sektor pertanian, pertambangan dan penggalian menyebabkan kenaikan kesempatan kerja dalam perekonomian Kota Bogor sebanyak 4,617 orang. Oleh sebab itu dapat dikatakan bahwa pedagang kaki lima di setiap sektor memiliki pengaruh dan kontribusi positif bagi kesempatan kerja dalam perekonomian Kota Bogor.

Dari hasil analisis tersebut terlihat bahwa perubahan terbesar setelah mengeinternalisasikan pedagang kaki lima terjadi pada sektor listrik, gas, air 
bersih dan bangunan, yaitu sebesar 8,037 yang mengartikan bahwa permintaan akhir pedagang kaki lima pada sektor listrik, gas, air bersih dan bangunan memberikan kenaikan atau penambahan kesempatan kerja pada perekonomian Kota Bogor yang paling besar dibandingkan dengan sektor lainnya. Hal ini mengindikasikan bahwa pedagang kaki lima pada sektor ini memiliki kontribusi yang paling besar terhadap perubahan kesemapatan kerja di Kota Bogor. Sedangkan kontribusi terendah diberikan oleh pedagang kaki lima pada sektor perdagangan, hotel dan restoran, pengangkutan dan komunikasi yaitu sebesar 0,713.

\subsection{Keterikatan Antara Sektor (Linkages)}

Selain digunakan untuk mengetahui angka pengganda (multiplier) analisis input-output juga dapat digunakan untuk mengetahui keterkaitan antar sektorsektor, yang dalam hal ini digunakan untuk melihat dampak dari output suatu sektor terhadap sektor yang lainnya. Dampak dari satu sektor terhadap sektor lainnya menunjukkan bahwa setiap sektor akan saling mempengaruhi satu sama lainnya. Selain itu pula dengan analisis keterkaitan antar sektor-sektor ini dapat juga digunakan untuk menentukan sektor yang dapat dijadikan sektor unggulan atau sektor kunci dalam suatu perekonomian. Di mana sektor yang memiliki keterkaitan paling tinggi berarti memiliki potensi menghasilkan output produksi yang tinggi pula.

Sektor dengan angka keterkaitan tinggi pada umumnya akan menghasilkan tambahan pendapatan rumah tangga dan tambahan lapangan pekerjaan tertinggi yang hal ini dapat diketahui dari mengkonversi output ke pendapatan rumah tangga dan angka pengganda kesempatan kerja. Keterkaitan antar sektor-sektor dikategorikan dalam dua bentuk, yaitu :

1. Keterkaitan ke belakang (backward linkages).
Asumsi dalam analisis ini adalah bahwa dengan adanya peningkatan output sektor tertentu akan mendorong peningkatan output sektor-sektor lainnya. Dimisalkan jika terjadi peningkatan output sektor-i akan menyebabkan meningkatnya permintaan input sektor-i. Input sektor-i tadi ada yang berasal dari sektor-i sendiri dan ada pula yang berasa dari sektor lain (misalkan sektor-j). Oleh sebab itu sektor ini akan meminta output sektor-j lebih banyak daridapa sebelumnya untuk dijadikan input guna melakukan proses produksi, yang berarti di sini menunjukkan bahwa sektor-j harus melakukan peningkatan jumlah output. Peningkatan jumlah output sektor-j selanjutnya akan meningkatkan permintaan input sektor-j itu sendiri, yang berarti pula harus ada peningkatan output sektor-j sektor lainnya. Kondisi ini akan berlangsung seterusnya, di mana akan terjadi keterkaitan antar sektorsektor industri tersebut dalam suatu perekonomian. Keterkaitan antar sektorsektor industri yang seperti ini disebut dengan keterkaitan ke belakang. Hal ini disebabkan karena keterkaitannya bersumber dari mekanisme penggunaan input produksi.

Jika output sektor-i mengalami peningkatan yang diakibatkan oleh peningkatan permintaan akhir sektor-i, maka akan terjadi peningkatan input produksi sektor-i secara langsung. Hal ini dapat dikatakan bahwa peningkatan penggunaan input adalah peningkatan output karena total input yang digunakan adalah sama dengan total output yang dihasilkan. Misalnya jika terjadi peningkatan satu unit uang sektor pertanian, akan meningkatkan pula pertumbuhan industri-industri lain yang merupakan input sektor pertanian, seperti industri pupuk, benih pertanian, alat-alat pertanian dan lain sebagainya.

2. Keterkaitan ke depan (forward linkages)

Keterkaitan ke depan dilakukan dengan cara menghitung total output yang tercipta akibat dari meningkatnya 
output suatu sektor industri melalui mekanisme distribusi output dalam perekonomian. Misalkan terjadi peningkatan output sektor-i, maka tambahan output tersebut akan didistribusikan ke sektor-sektor produksi lain di dalam perekonomian tersebut (termasuk sektor-i itu sendiri). Oleh sebab itu jika terjadi peningkatan satu unit output sektor-i, akan menyebabkan peningkatan output total dalam perekonomian melalui mekanisme output.

Peningkatan yang terjadi tidak hanya di satu sektor saja, hal ini dapat pula berdampak pula secara tidak langsung terhadap terhadap peningkatan output sektor lainnya lagi. Jika diketahui nilai keterkaitan ke belakang secara langsung dan keterkaitan totalnya, maka akan diperoleh nilai keterkaitan ke belakang secara tidak langsung yang besarnya adalah selisih antara kedua nilai keterkaitan tersebut.

Dengan kata lain keterkaitan ke depan menunjukkan peningkatan produksi suatu sektor (misalkan sektor-i), akan mendorong pertumbuhan produksi sektor-sektor yang mempergunakan produk (output) dari sektor-i tersebut. Misalkan dengan meningkatnya sektor pengolahan (produk karet), akan meningkatkan pertumbuhan industri lainnya seperti industri sandal sepatu, industri ban dan lain sebagainya.

Nilai keterkaitan antar sektor-sektor ke belakang dan ke depan berdasarkan analisis sebelum dan setelah meninginternalisasikan pedagang kaki lima dalam perekonomian Kota Bogor dijelaskan sebagai berikut:

Tabel 7. Analisis Keterkaitan Antar Sektor-sektor

\begin{tabular}{|c|c|c|c|c|c|c|}
\hline \multirow[t]{2}{*}{ Sektor } & \multicolumn{2}{|c|}{$\begin{array}{l}\text { Keterkaitan Sebelum } \\
\text { Menginternalisasi PKL } \\
\text { (IO) }\end{array}$} & \multicolumn{2}{|c|}{$\begin{array}{l}\text { Keterkaitan Sesudah } \\
\text { Menginternalisasi PKL } \\
(\text { IO*) }\end{array}$} & \multicolumn{2}{|c|}{$\begin{array}{c}\text { Perubahan } \\
\text { (persen) }\end{array}$} \\
\hline & Backward & Forward & Backward & Forward & Backward & Forward \\
\hline 1. & 1,251 & 0,514 & 1,252 & 0,501 & 0,011 & $-2,371$ \\
\hline 2. & 0,944 & 1,289 & 0,936 & 1,276 & $-0,869$ & $-1,062$ \\
\hline 3. & 0,662 & 1,118 & 0,703 & 1,151 & 6,212 & 2,957 \\
\hline 4. & 0,956 & 1,043 & 0,940 & 1,045 & $-1,692$ & 0,183 \\
\hline 5. & 1,185 & 1,034 & 1,168 & 1,025 & $-1,424$ & $-0,879$ \\
\hline
\end{tabular}

Sumber : pengolahan data

Keterangan :

- 1 = Pertanian, Pertambangan, Penggalian

- 2 = Industri Pengolahan

- 3 = Listrik, Gas, Air bersih, Bangunan

- 4 = Perdagangan, Hotel dan Restoran, Pengangkutan dan Komunikasi

- 5 = Keuangan, Perbankan, Jasa-jasa

Keterkaitan kebelakang atau disebut juga daya penyebaran menunjukkan besarnya output domestik yang dihasilkan oleh seluruh sektor ekonomi yang ditimbulkan oleh kenaikan 1 unit permintaan akhir dari suatu sektor tertentu. Semakin tinggi keterkaitan ke belakang suatu sektor berarti semakin tinggi kemampuan sektor tersebut dalam mendorong pertumbuhan ekonomi. Semakin tinggi indeks daya penyebaran (IBlj) suatu sektor ekonomi akan semakin besar pula pengaruh sektor tersebut terhadap pertumbuhan sektor-sektor lainnya, yang berarti pula bahwa keterkaitan/ketergantungan sektor tersebut terhadap sektor lainnya cukup besar.

Keterkaitan kedepan (forward linkage) atau derajat kepekaan suatu sektor menunjukkan keterkaitan antarsektor yang dilihat dari besarnya output yang dihasilkan oleh suatu sektor sebagai akibat dari peningkatan permintaan akhir seluruh sektor ekonomi. Keterkaitan antar-sektor ini disebut dengan. Indeks 
derajat kepekaan (IFLj) merupakan ukuran total dampak terhadap output suatu sektor akibat penggunaan output sektor tersebut oleh sektor lainnya sebagai input. Semakin tinggi nilai indeks derajat berarti semakin tinggi pula daya kepekaan sektor tersebut karena pertumbuhan sektor-sektor lain yang menggunakan sektor tersebut untuk proses produksinya.

Berdasarkan hasil analisis diketahui untuk keterkaitan ke belakang sektor pertanian, pertambangan dan penggalian memiliki IBlj yang paling besar dibandingkan dengan sektor lainnya, yaitu sebesar 1,251. Kemudian setelah menginternalisaikan pedagangan kaki lima, sektor ini juga masih memiliki nilai IBlj yang paling besar dibandingkan sektor lainnya, yaitu sebesar 1,252. Namun demikian sektor ini bukan merupakan sektor unggulan di Kota Bogor, karena untuk menjadi sektor ungulan disyaratkan memiliki nilai IBlj dan IFLj yang paling besar di bandingkan dengan sektor lainnya. Dari hasil analisis keterkaitan kebelakang diketahui bahwa sektor yang memiliki nilai IFLj paling besar adalah sektor industri pengolahan, yaitu sebesar 1,289. Kemudian setelah menginternalisasikan pedagang kaki lima sektor industri pengolahan masih menjadi yang terbesar dibandingkan sektor lainnya, yaitu sebesar 1,279.

Nilai perubahan keterkaitan ke belakang atau pun ke depan setelah menginternalisasikan pedagang kaki lima ada positif (meningkat) dan ada pula yang negatif (menurun). Nilai perubahan positif mengindikasikan bahwa kegiatankegiatan usaha yang dilakukan oleh pedagang kaki lima telah mampu meningkatkan keterkaitan, baik ke belakang maupun ke depan terhadap sektor-sektor di Kota Bogor. Kondisi ini terjadi pada sektor pertanian, pertambangan dan penggalian serta sektor listrik, gas, air bersih dan banngunan untuk keterkaitan ke belakang. Sedangkan untuk keterkaitan ke depan terjadi pada sektor listrik, gas, air bersih dan bangunan serta sektor Perdagangan, Hotel dan Restoran, Pengangkutan dan Komunikasi.

Nilai keterkaitan untuk sektor listrik, gas, air minum dan bangunan setelah menginternalisasikan pedagang kaki lima memiliki nilai positif, baik ke belakang maupun ke depan, sehingga dapat dikatakan bahwa dengan pedagang kaki lima telah mampu meningkatkan keterkaitan sektor ini baik ke belakang maupun ke depan.

\section{SIMPULAN DAN SARAN}

\section{Simpulan}

Keberadaan pedagang kaki lima perkotaan tidak dapat dipandang sebagai sektor yang marginal, pedagang kaki lima memberikan kontribusi positif terhadap perekonomian perkotaan, dari hasil penelitian dapat disimpulkan :

1. Keberadaan kaki lima di setiap sektor memberikan kontribusi atau pengaruh positif bagi total output perekonomian Kota Bogor. Perubahan terbesar terjadi pada sektor industri pengolahan, yaitu sebesar 6,162 Sedangkan kontribusi terendah pada sektor perdagangan, hotel dan restoran, pengangkutan dan komunikasi sebesar 0,854 .

2. Pedangan kaki lima pada setiap sektor ekonomi memiliki pengaruh dan kontribusi yang positif terhadap pendapatan rumah tangga. Perubahan terbesar setelah mengeinternalisasikan pedagang kaki lima terjadi pada sektor listrik, gas, air bersih dan bangunan, yaitu sebesar 7,838 . Kontribusi terendah diberikan oleh pedagang kaki lima pada sektor perdagangan, hotel dan restoran, pengangkutan dan komunikasi sebesar 0,715.

3. Keberadaan pedagang kaki lima di setiap sektor memberikan kontribusi atau pengaruh positif bagi total penyerapan tenaga kerja Kota Bogor. Perubahan terbesar setelah 
mengeinternalisasikan pedagang kaki lima terjadi pada sektor listrik, gas, air bersih dan bangunan sebesar 8,037. kontribusi terendah diberikan oleh pedagang kaki lima pada sektor perdagangan, hotel dan restoran, pengangkutan dan komunikasi yaitu sebesar 0,713.

4. Keterkaitan ke belakang sektor pertanian, pertambangan dan penggalian memiliki IBlj yang paling besar dibandingkan dengan sektor lainnya. Keterkaitan kebelakang diketahui bahwa sektor yang memiliki nilai IFLj paling besar adalah sektor industri pengolahan.

\section{Keterbatasan Penelitian}

1. Dikarena setiap daerah tidak mengupdate secara periodik/tidak membuat tabel transaksi input output disebabkan membutuhkan biaya yang mahal dan waktu yang relatif lama, dalam penelitian ini menggunakan tabel transaksi input output Kota Bogor tahun 2010.

2. Dikarenakan sel-sel pada tabel transaksi IO Kota Bogor tidak terisi secara lengkap sehingga dimungkinkan adanya misdate, dilakukan agregasi pada tabel transaksi input output Kota Bogor tahun 2010 menjadi lima sektor.

3. Informasi kontribusi pedagang kaki lima terhadap sektor-sektor perekonomian menggunakan teknik judgment kepada para pihak yang terkait, untuk kedepan disarankan untuk melakukan penelitian dengan survei pada sektor-sektor perekonomian.

\section{Saran}

1. Penataan dan pendataan pedagang kaki lima di Kota Bogor perlu dilakukan secara periodik agar dapat diketahui potensi ekonomi, tidak peruntukan fasilitas umum kota.

2. Perlunya pembentukan assosiasi pedagang kaki lima agar dapat lebih mudah dalam pengawasan dan upaya peningkatan kualitas.

\section{DAFTAR PUSTAKA}

Alexander, Jennifer dan Paul, A. 1991. http: Ilwww.jstor.org\pss\2803879.

Arief, S. 1993. Metode Penelitian Ekonomi. LPFE-UI : Jakarta.

Arsyad, L. 1999. Pengantar Perencanaan dan Pembangunan Ekonomi Daerah. BPFE : Jogjakarta.

Artina Vita Ningrum. 2015. Peran Sektor Informal Dalam Perekonomian Indonesia. Universitas

Diponegoro; Semarang

Badan Pusat Statistik. 2016. Survai Tenaga Kerja Nasional. Jakarta. 2013. Survai Ekonomi Sosial Nasional (Susenas). Jakarta.

2016. Profil Kemiskinan di Indonesia Maret 2009. Jakarta.

2010. Data dan

Metodologi Untuk Kajian Sektor Informal di Indonesia. Jakarta.

Bappenas. 2009. Kajian Evaluasi

Pembanguan Nasional, Peran

Sektor Informal Sebagai Katup Pengaman Masalah

Ketenagakerjaan. Kedeputian

Evaluasi Kinerja Pembangunan,

Badan Perencanaan Pembangunan

Nasional : Jakarta. . 2010. Kajian Penyusunan

Stretagi Penanggulangan

Kemiskinan Pada Sektor Informal.

Direktorat Penanggulangan

Kemiskinan Nasional. Bappenas.

Bernabe, Sabine. 2002. Informal Employment in Countries in

Transition : A Conceptual

Framework, Centre Analysis of

Social Exclusion. London School of Economics : London.

Cuevas, S.et.all. 2008. Informal Employment in Indonesia, ADB. 
Daryanto, A dan Yundy, H. 2010. Analisis Input Output dan Social Accounting Matrix Untuk Pembangunan Ekonomi Daerah. IPB Press : Bogor.

Effendi, T., Noer. 1996. Sumber Daya Manusia, Peluang Kerja dan Kemiskinan. Tiara Wacana : Jogjakarta.

Firnandy. 2002. Studi Profil Pekerja di Sektor Informal dan Arah Kebijakan ke Depan. Direktorat Ketenagakerja dan Analisis Ekonomi : Jakarta.

Manning, C. dan Effendi, T., N . 1993. Sektor Informal. Urbanisasi, Pengangguran, dan Sektor Informal di Kota. Manning and T. N. Effendi. Jakarta, Yayasan Obor Indonesia.

Muhammad Ihsan dan Kharisma Susetyo. 2013. Pengaruh Sektor Informal Terhadap Penyerapan Angkatan Kerja di Jakarta. UIN Syarif Hidayattulah : Jakarta.

Mus Mualim dan Bin Raudha A H. 2009. Menata Sektor Informal di Perkotaan. Program Magister Ilmu Ekonomi Universitas Brawijaya : Malang.

Prasetya, S.,G.2016. The Roles of Syariah Micro Finance Institution (LKSM) in Eliminating The Poverty in Indonesia (Case Study of Baitul Maal Wat Tamwil). The Accounting Journal of Binaniaga. Vol 01.No.2.

Rachbini, D., J dan A. Hamid. 1994. Ekonomi Informal Perkotaan : Gejala Involusi Gelombang Kedua. LP3ES : Jakarta.

Modern : Perkembangan

Pemikiran Dari Klasik Hingga

Keynesian Baru. PT. Raja

Garfindo Persada : Jakarta.

Retno Widjajanti, 2012. Karakteristik Aktivitas Pedagang Kaki Lima di Ruang Kota (Studi Kasus: Kawasan Pendidikan Tembalang,
Kota Semarang). Universitas Diponegoro : Semarang

Winarso H dan Gede B. 2008. Sektor Informal yang Terorganisasi : Menata Kota Untuk Sektor Informal. Kelompok Keahlian Perencanaan dan Perancangan Kota, Sekolah Arsitektur, Perencanaan dan Pengembangan Kebijakan, Institut Teknologi Bandung : Bandung. 